\title{
Physiochemical and nutritional values of some blends of vegetable oils with palm olein compared to some cooking oils of Tamouin Cards
}

\section{Rasha Maher El-Sayed Bhnsawy}

Special Food and Nutrition Dept., Food Technology Research Institute, Agricultural Research Center, Giza, Egypt

\section{ABSTRACT}

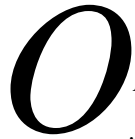

il blending has been recognized as one of the most potent solution in producing vegetable oils with good storage stabilities and optimum fatty acids compositions. Palm olein is stable against rancidity and oxidation. This study was conducted to identify the best oil blends in terms of physicochemical properties between palm olein, sunflower and soybean oil and food safety nutrition (The more resistance cooking oil against degradation process and formation of free radicals). Palm olein, sunflower and soybean oils were blended at different ratios of (50:25:25), (60:20:20) and (70:15:15) to obtain three new blended at different ratios of (50:25:25) palm olein: sunflower: soybean oil shows the best properties after being mixed compared to other blends and tamouin cards cooking oil. It passed the viscosity test and has significantly moderate cloud point of $8.2^{\circ} \mathrm{C}(p<0.05)$ which means it can be stored at low temperature $\left(9^{\circ} \mathrm{C}\right)$. This blend also has significantly smoke point $\left(236^{\circ} \mathrm{C}\right)$, high iodine value of $126.28 \mathrm{~g} \mathrm{I} / \mathrm{lo0g}(\mathrm{p}<0.05)$, low peroxide content of $4.68 \mathrm{meq} \mathrm{O}_{2} / \mathrm{kg}$ and has significantly the lowest acid value of $0.16 \%$ $(p<0.05)$. Fatty acid composition has shown that it has high unsaturated oleic acid, C18: 1 (25.05\%) and relatively high oxidative stability $(9.25 \mathrm{~h})$ compared to other oil blends. The chips fried in blends contain palm olein showed the best sensory evaluation. Therefore, the blend of (25:25) (sunflower: soybean) with $50 \%$ palm olein is recommended for deep-frying and can be kept longer due to its stability and high smoke point.

KEY-WORDS: Oil blend - Palm olein oil -Sunflower oil - Soybean oil Tamouin cards oil-Melting point -oxidative stability - fatty acid-nutritive value 
Rasha Maher El-Sayed Bhnsawy

INTRODUCTION

One of the issues surrounding the oils is the stability of the oils themselves. This is due to auto-oxidation and photo-oxidation that occurs during processing and storage, (Choe and Min 2006).

Oils using by the processor depends in part by market considerations. The end flavor could dictate what type of oil is to be used Tabee $\boldsymbol{e t} \boldsymbol{a l}$ (2008). Consumer preference might force the processor to minimize the level of saturated fats in the final product. (Increasing the level of unsaturated oils would result in greater oil instabilityan important consideration when selecting frying machinery.)

Some oils solidify under ambient conditions, so effective oil-blending techniques associated with correct oil storage and transfer equipment need to be taken into account.Processors have to ensure that their oil is suited to their particular cooking technique (Stevenson et al (1984).
Furthermore, some oils may need to have a chelating agent (to prevent particle buildup) added to fresh oil before it is poured into the fryer; in addition to antioxidants or anti-foam additives(Gertz et al (2000). The instability of oils can also lead to undesirable taste and flavor of oil, decomposing nutritional quality and also production of toxic compounds.

Another problem is the amount of saturated fatty acids in oils. The world has come to realize that high amount of saturated fats in foods are one of the main causes of coronary heart diseases such as atherosclerosis. Ramsden et al (2013) and IdunAcquah et al (2016) stated that increasing the intake of unsaturated and polyunsaturated fats can help in reducing the risk of coronary heart diseases.

Mozaffarian et al (2005); Willett (2007) and Griffin (2008) stated that only omega-3 is significant in preventing cardiovascular diseases while omega-6 are not.However, these unsaturated fatty acids are susceptible to oxidation (Gharby $\boldsymbol{e t}$ al (2014). 
Physiochemical and nutritional values of some blends of vegetable oils with palm olein compared to some cooking oils of Tamouin Cards

Rasha Maher El-Sayed Bhnsawy

Lipid oxidation has a negative impact on the functionality of raw materials, sensory and nutritional quality of food, and causes economic losses (Matthaus et al (2010). The most noticeable result of lipid oxidation is the appearance of an unpleasant flavor often referred to rancid, which modifies the sensory characteristics of the food, so its assessment by the consumer (Velasco and Dobarganes (2002); Frankel (2007); Choe and Min (2006) and Gharby et al (2012) .

Lipid oxidation also led to a change in color and sometimes texture, as well as the loss of essential nutrients and micronutrients (Choe and Min (2006). Finally, lipid oxidation can lead to the formation of potentially toxic oxidation products (oxycholesterol, malonaldehyde, endoperoxides, acrolein, polymeric peroxides) (Kim and Min (2008) and Farhoosh and

EsmaeilzadehKenari (2009).

The oxidation of
unsaturated fatty acids
phenomena has been studied for
more than half a century
(Labuza and Dugan (1971) and Judde (2004). The report of
Lipid oxidation is an autocatalytic reaction (Frankel (1984) and Leong et al (2015). It is a sequence of radical reactions drop broadly into three stages: initiation, propagation and termination Judde (2004). The oxidation of unsaturated fatty acids may result from three reaction pathways, depending on the environment and initiators.

The undesirable changes in oils during frying partially depend on the unsaturation degree of fatty acids. Therefore, it is very important to choose the right frying oil to retard oil deterioration. High oxidative stability, high smoke point, low foaming, low melting point and bland flavor are important characteristics of good frying oils (Kochhar 2000).

Blending is a good option for improve melting point, the oxidative stability, iodine value and peroxide value. Oils with lower values of viscosity, density and low melting point are highly desirable to consumers. Viscosity is related to the chemical properties of the oils such as chain length and saturation/unsaturation. It 
Physiochemical and nutritional values of some blends of vegetable oils with palm olein compared to some cooking oils of Tamouin Cards

Rasha Maher El-Sayed Bhnsawy

decreases with an increase in unsaturation and increases with high saturation and polymerization, (Kim et al (2010).

Based on study by Basoglu et al (1996), addition of $20 \%$ palm olein with soft oils showed the desired clarity during shelf storage. Blending of oil can also reduce the risk of cloudy and partial crystallization in palm olein (Siddique et al (2010).

Palm oil, which is the second largest source of oil in the world, next to soybean oil, is currently the oil most used for frying (FEDIOL2012). It has a good oxidative stability due to its high degree of saturation and mono unsaturation.

The presence of Vitamin E (tocopherol) in palm oil promotes the oxidative stability against rancidity reaction compared to other vegetable oils (Tawfik and Huyghebaert (1999).

Recently, palm oil has become the second most consumed oil all over the world with a competitive price compared to other edible oils. However, due to its high melting point, it is not gaining due status in spite of being rich in natural antioxidants, vitamins, high oxidative stability and having a long shelf life (Edem, 2002). Palm oil is also rich in $\beta$-carotene which helps to prevent liver and lung cancer (Murakoshi et al (1992).

The objectives of this study were to finding some blendsof sunflower oil and soybean oil with palm olein characterize by low melting point, peroxide andhigh oxidative stability. And investigate some physicochemical properties of these blends (refractive index, cloud points, melting point, smoke point, free fatty acid percentages, iodine values, peroxide values, fatty acid compositions and oxidative stability) comparison withother collected samples of Tamouin Card oil ( the oil which Egypt governorate distributed on Tamouin Card and is packed by some factories) .

MATERIALS \& METHODS 
Physiochemical and nutritional values of some blends of vegetable oils with palm olein compared to some cooking oils of Tamouin Cards

Rasha Maher El-Sayed Bhnsawy

Materials:

All chemicals, reagents and solvents used in this study wereanalytical grade and obtained from Professional Labs (Cornal lab.).

Samples of sunflower, soybean and palm olein oils were obtained from Arma and Safola companies $\left(10^{\text {th }}\right.$ of Ramadan) and the other samples oils of Tamouin Cards were collected from different provinces in Egypt in $2014 / 2015$.

\section{Preparation of oil blends:}

Sunflower oil, soybean oil and palm olein were blended at different ratios as present in table (1) and heating to $40^{\circ} \mathrm{C}$ with magnetic stirrer according to Siddique et al., (2010).

\section{Physicochemical analysis:}

1- Cloud point, iodine value, peroxide value and free fatty acids were estimated according to the methods described in (AOCS official methods 1995 a, b).

2-Smoke point, moisture content, viscosity and density were carried out according to the analytical methods described by (AOCS official methods1995 c).

3- Acid value, peroxide value, saponification value and iodine value were carried out according to the analytical methods described by (AOCS official methods $1995 \mathrm{~d}$ ).

4- Fatty acid content: approximately $100 \mathrm{mg}$ of all the blended oil were weighed and put into universal bottle. Then 5 $\mathrm{ml}$ of hexane and $250 \mu \mathrm{l}$ of sodium methoxide solution was added and capped tightly. The mixture was vortexed for $1 \mathrm{~min}$, paused every $10 \mathrm{~s}$ to allow the mixture of oil to collapse. Next, $5 \mathrm{ml}$ of saturated sodium chloride was added into the bottle cap and shaken vigorously for $15 \mathrm{~s}$ and left the bottle for 10 minutes. Finally, the hexane (top layer) was transferred into a vial containing sodium sulfate. About $0.5 \mu \mathrm{l}$ of fatty acid methyl esters(FAMEs) was injected into gas chromatography (Hewlett Packard 6890, GC model G1530A) equipped with flame ionization detector (Hewlett Packard 6890, GC model G1530A) and fitted with a BPX70 capillary column $(30 \mathrm{~mm}$ 
Physiochemical and nutritional values of some blends of vegetable oils with palm olein compared to some cooking oils of Tamouin Cards

Rasha Maher El-Sayed Bhnsawy

$\times 0.32 \mathrm{~mm} \times 0.25 \mu \mathrm{m}$ ) to obtain individual peaks of FAMEs. The injector and detector temperatures were $250^{\circ} \mathrm{C}$. The column temperature was held at $115^{\circ} \mathrm{C}$ and increased to $180^{\circ} \mathrm{C}$, held for 10 minutes. It continued rising to $240^{\circ} \mathrm{C}$ and held for 10 minutes, the increasing rate is $8^{\circ} \mathrm{C} / \mathrm{min}$. The carrier used was nitrogen set at flow rate 16 $\mathrm{ml} / \mathrm{min}$ (Nielsen, 2010).

5- Oxidative stability: oil oxidative stability was evaluated by the Rancimat method (Gharby et. al., 2011). Stability was expressed as the oxidative induction period (IP, hrs) measured at $120^{\circ} \mathrm{C}$ on a Rancimat 743 (Metrohm Co, Basel) apparatus using $3 \mathrm{~g}$ of oil sample with an air flow of 20 $\mathrm{L} / \mathrm{hr}$. Volatile oxidation products were stripped from the oil and dissolved in cold water, whose conductivity increased progressively. The time taken to reach a level of conductivity was measured

\section{Statistical analysis:}

All analysis were done in triplicate $(n=3)$ and the data were statistically analyzed by one-way analysis of variance (ANOVA) procedure, using Minitab software (Snedecor and Cochran (1980). Significant differences $\quad(p<0.05)$ between means were determined.

\section{RESULTS \& DISCUSSION}

\section{Physical properties:}

The data in table (2) show some physical properties of three blends of oils containing palm olein and other five collected samples without palm olein obtained from different provinces in Egypt.

1- Smoke point: when fats or oils are heated to high temperature, decomposition occurs and finally a point is reached where fat is broken down to glycerol and free fatty acids and produce bluish smoke .This point is called the (smoke point) The glycerol is then further broken down to acrolein which is also a component of the smoke. The smoke point also marks the beginning of both flavor and nutritional degradation giving an unpleasant and disagreeable flavor to the food. 
Rasha Maher El-Sayed Bhnsawy

Therefore, when selecting the oil for frying must be having a higher smoke point, most vegetable cooking oils have smoke points between $265^{\circ} \mathrm{C}$ and $360^{\circ} \mathrm{C}$, (Acquah et al 2016).

Based on this information and from the data in table (2) it is clear that the three prepared blends were the prefer which recorded the highest degree in smoke point; $238^{\circ} \mathrm{C}, 238^{\circ} \mathrm{C}$ and $236^{\circ} \mathrm{C}$ for Blend $1(50 \%$ palm olein $+25 \%$ sunflower oil $+25 \%$ soy oil) , blend 2 (60\% palm olein $+20 \%$ sunflower oil $+20 \%$ soy oil) and blend 3 (70\% palm olein $+15 \%$ sunflower oil $+15 \%$ soy oil ) respectively. While sample 3 showed the lowest degree $230 \mathrm{oC}$ in smoke point.

2- Viscosity: From the same table it could be noticed that the viscosity of the three blends was increased compared to the other five samples and this may be due to the palm olein which content about $45 \%$ saturated fatty acid specially palmitic acid. Although, the viscosity of blend 1 (50 CTP) approaching from the other collected samples (don't content palm olein) which ranged from $(40$ - 50 CTP).

Oil viscosity depends on molecular structure and decreases with the unsaturation of fatty acids. It may be due to the ( $\pi$ bonds) that make the bonding more rigid and rotation between $\mathrm{C}-\mathrm{C}$ bonds becomes more strenuous. Also, the extended chain makes the flow easier and reduces viscosity. It was observed that also viscosity decreases linearly with the increase in low viscous oil portion in the blends at $37^{\circ} \mathrm{C}$ especially for the blends 1,2 and 3. This might be due to the presence of fat crystals that coalesce together and need more time for destruction while they increases the friction between the layers and this results in a sharp increase in viscosity, (Siddique, et al.2010).

3- Cloud point: is a point where oil starts to turn cloudy and no longer completely soluble in order to determine its physical resistance towards lower temperature. This analysis is important in order to identify the minimum temperature of storage 
Physiochemical and nutritional values of some blends of vegetable oils with palm olein compared to some cooking oils of Tamouin Cards

Rasha Maher El-Sayed Bhnsawy

for oil. Also the data in table (2) show that blends, 1, 2 and 3 had the highest cloud point temperature which were $8.2,8.6$ and $9.3{ }^{\circ} \mathrm{C}$ respectively compared to the other five samples which showed the lowest cloud point temperature ranged from 6.2$7.7^{\circ} \mathrm{C}$. This is due to also the high cloud point of palm oleinwhich due to the high content of saturated fatty acids (Roiaini, et al 2015). The value of cloud points of palm olein is ranged from $10.7-14.3^{\circ} \mathrm{C}$ in some studies.

\section{Chemicals properties}

The data in table (3) show some chemical properties of three blends of oils containing palmolein and other five collected samples without palmolein.

1- Acid value: during frying, oil is exposed to air and moisture at elevated temperatures resulting in the hydrolysis of triacylglycerol. This leads to a release of free fatty acids. The released fatty acids are more susceptible to thermal oxidation and cause off-flavors and odors in the frying medium and fried foods(Bangash and Khattak 2006) and Firestone (1993). Hydrolysis of triglycerides and deterioration of oil also increase free fatty acid. Other factors which increase fatty acid level in cooking oils are exposure to light, lipase enzyme and high temperature (Gulla and Waghray (2012).If free fatty acids are in excess in plasma they may cause several health hazards, such as obesity and type 2 diabetes (Mishra and Manchanda 2012).

In table (3) acid value showed decreasing in blend 1, 2 and 3 which recorded 0.1435 , 0.1357 and 0.1186 respectively compared to the other samples. The highest decrease in acid value was found in blend 3 while sample 6 showed the highest increase, 0.2215 . The acid value which measures how many fatty acids are cleaved from their parent molecules (triglycerides or phospholipids),so it expresses on the stability of the oils. That is mean adding of palm olein to blends of sunflower oil and soy oil increasing their stability. This may be due to their content of 
Physiochemical and nutritional values of some blends of vegetable oils with palm olein compared to some cooking oils of Tamouin Cards

Rasha Maher El-Sayed Bhnsawy

antioxidants such as $\beta$-carotene (Siddique et al (2010).

2- Peroxide value: is a common method used to measure lipid oxidation, and is suitable for measuring peroxide formation in the early stages of oxidation Unsaturated fatty acids presence will easily react with oxygen to form peroxides ( Roiaini, et al., 2015).

In table(3) blends 1, 2 and 3 showed decreasing in peroxide value 4.6, 5.2 and 5.9 compared to the five other samples which recorded 8.5, 8.9, $9.1,7.8$ and $6.8 \mathrm{meq} / \mathrm{kg}$ for 1,2 , 3, 4 and 5 respectively. This indicated the natural antioxidants in palm olein lowered the oxidation process compared to other samples. But all values of peroxide stayed under the acceptable the maximum levels (up to $10 \mathrm{meq}$ of active $\mathrm{O}_{2} / \mathrm{Kg}$ ) (Codex-Stan 210-1999).

Some studies reported that the initial peroxide value was found to have occurred around 2.5 to 5 meq $\mathrm{O}_{2} / \mathrm{kg}$ oil which indicates a relatively good quality of these oils but after exposure to light and air at room temperature the peroxide value increased to a maximum value. The peroxide value for palm olein-canola blends in the initial value and after 3 weeks was found to be almost the same, although after 8 weeks it was lower than the others, (Siddique, et al 2010).

3- Saponification value: The saponification value was found to increase with storage time. This trend explains that with the long storage of these oils, fatty acids are likely to be formed which increase the saponification value, (Siddique et al 2010).

Saponification value of the prepared blends showed a slight decrease compared to the other samples. Blend 1 showed the lowest value 187.54 while sample 6 showed the highest value $195.24 \mathrm{mg} \mathrm{KOH} / \mathrm{g}$.

4- Iodine value: is a measure of the total number of unsaturated double bonds present in oil. The differences in iodine values of oils during frying are also good indicators of deterioration in the oils (CheMan and Jasvir, 2000). Oxidation, which consists of a complex series of chemical reactions, is characterized by a 
Physiochemical and nutritional values of some blends of vegetable oils with palm olein compared to some cooking oils of Tamouin Cards

Rasha Maher El-Sayed Bhnsawy

decrease in the total unsaturated content of the oil due to the abstraction of hydrogen adjacent to a double bond and the formation of free radicals (Choe and Min (2006). The decrease in iodine values can be attributed to the destruction of double bonds by oxidation and polymerization (Roiaini et al (2015)

From the data in table (3) it could be observed that iodine values were higher in palmolein blends than those of the other samples. Blend 1 recorded the lowest value 114.92 while sample 7 recorded the highest value $128.59 \mathrm{~g} / 100 \mathrm{~g}$. The iodine value of palm olein was initially low $(58.01 \mathrm{~g} / 100 \mathrm{~g})$, but after it was added to the blends of canola and olive oils at different ratios, the values of iodine values for these blends increased, (Roiaini et al 2015).The increment of iodine values is due to the fact that after the oils are blended together, their degree of unsaturation changed leading to changed iodine values (Siddique et al 2010). When oil with high content of linoleic acid is blended with palmolein, the linoleic acid tends to migrate into the oil blends (Abdulkarim et al 2010).

The initial oxidative stability by Rancimat

The oxidative stability index of oils (induction period time) was given in Table (4) The Rancimat induction time at 120 ${ }^{\circ} \mathrm{C}$ varied from $1.64 \mathrm{~h}$ to $9.25 \mathrm{~h}$ in the oils blends and samples. Blend 1 was the higher stable $(9.25 \mathrm{~h})$ followed by (7.52 and $6.13 \mathrm{~h}$ ) for blend 2 and 3 respectively. While the oil samples were the less stable specially sample 5 which was $(1.64 \mathrm{~h})$, this is due to the palm olein. Palm olein oil was the most stable $(15.5 \mathrm{~h})$ followed by sunflower oil $(5.5 \mathrm{~h})$. The high stability of palm olein oil (15.5 h) is most likely due to its fatty acids composition which contained nearly $40 \%$ of saturated fatty acids, (Gharby $\boldsymbol{e t}$ al. 2014).

\section{Fatty acid compositions}

The Fatty acid compositions of oil blends and the collected samples are shown in table (5). The main fatty acids detected in all blends and 
Rasha Maher El-Sayed Bhnsawy

samples were, lenoleic, oleic, palmitic, lenolenic and stearic. Sample 4 showed the highest content of lenoleic acid (63.12 $\%$ ), sample 2 showed the highest content of oleic acid (26.51\%), blend 1 showed the highest content of palmitic acid (13.14\%) while sample 3 showed the highest content of lenolenic acid $(6.67 \%)$ and stearic acid (4.77\%).

On the other hand saturated, monounsaturated, and polyunsaturated fatty acids in the three blends were ranged from (15.41- 17.91), (24.88- 25.17) and (56.11- 58.73) \% respectively. This composition seems the closest to sample 1 (sunflower oil) which was content to $15.77,25.06$ and 58.68 $\%$ of saturated, monounsaturated and polyunsaturated fatty acids respectively. In similar study (Roiaini, et al. 2015) found that the proportion of polyunsaturated/monounsaturated fatty acid ratios were significantly decreased after adding palm olein to Canola and olive oils and reported that hence, increased the oxidative stability of the blends

\section{Sensory evaluation:}

The data in table (6) show sensory evaluation of potato chips fried in the prepared blends and the collected samples. It is clear that the three blends recorded the highest degree in all parameters of the sensory evaluation (color, taste, odor, texture and acceptance)and showed insignificant change between them and sample 3 . The Sensory evaluation of Potato chips fried in samples 1and 2 came in second place, while samples 4 and 5 showed the less degree insensory evaluation. Gulla and Waghray, (2012) reported that the flavour like ability of fried food is dependent upon consumer perception and is affected by the type of oil used and the length of time the oil has been heated or used for frying.

\section{CONCLUSIONS}

In this study, the quality and properties of the prepared blendsand samples of oils were evaluated through using differentparameters. Blends with Palm olein were found to be the most stable against oxidation and 
Rasha Maher El-Sayed Bhnsawy

food degradation for the palm olein: sunflower oil: soy oil blend $(50: 25: 25)$ it was found to has more resistance against oxidation and free radical formation (which its formation in food leads to a dangers diseases), followed by palm olein: sunflower oil: soy oil (60:20:20) and palm olein: sunflower oil: soy oil (70:15:15). This study will help the oil producing industry tofind the most economically nutritive viable oil blends for cooking purposes, as well as desirable physiochemical properties. Thus blending is a good choice by which we can manufacture more safe high nutritive edible oils of good characteristics and ensure their quality, and these results position the palm olein compared to other oils for use in cooking and frying food.

\section{REFERENCES}

Abdulkarim SM; Myat MW. and Ghazali HM (2010):

Sensory and physicochemical qualities of palm olein and sesame seed oil blends during frying of banana chips.

Journal of Agricultural

Science 2(4): 18-29.

American Oil Chemists' Society (AOCS) (1995a):

Method Cc 6-25. Official

Methods and

Recommended Practices of the American Oil Chemists' Society Champaign.

American Oil Chemists' Society (AOCS)(1995b): Method Ca 5a-40.Official Methods and Recommended Practices of the American Oil Chemists' Society Champaign.

American Oil Chemists' Society (AOCS)(1995c): Method Cd 1d-92. Official Methods and Recommended Practices of the American Oil Chemists' Society Champaign.

\section{American Oil Chemists' Society (AOCS)(1995d):}


Physiochemical and nutritional values of some blends of vegetable oils with palm olein compared to some cooking oils of Tamouin Cards

Rasha Maher El-Sayed Bhnsawy

Method Cd 8-53. Official

Methods

and

Recommended Practices

of the American Oil

Chemists'Society

Champaign.

Bangash FK and Khattak $H$ (2006):

Effect of deep fat frying on physic-chemical properties of

SilybumMarianum and sunflower seed oils. J.Chem. Soc. Pak.

Vol.28 no.2:121-124.

Basoglu FN; Wetherilt H;

Pala M; Yildiz M; Biringen $C$ and Unai, M(1996):

Improved quality of cooking and frying oil by blending palmolein, Proceeding of World Conference on Oil Seed and Edible Oil Processing,

Istanbul.159-168.

CheMan YB andJasvir I. (2000):

Effect of rosemary and sage extractson frying performance of refined, bleached and deodorized (RBD) palmolein during deep fat fryingFood Chem. 69, 301-307.

\section{Choe E and Min DB(2006):}

Mechanisms and factors for edible oil oxidation.

Compressive

Review in Food Science and Food Safety, 5:16986

Edem DO(2002):

Palm oil: Biochemical, physiological, nutritional, hematological and toxico-logical aspects: A review. Plant Foods for Human Nutrition (FormerlyQualitasPlanta rum) 57, 319-341.

Farhoosh R and Esmaeilzadehkenari $\mathbf{R}$ (2009):

Anti-Rancidity Effects of Sesame and Rice Bran Oils on Canola Oil during Deep Frying. Journal of the American Oil Chemists' Society. 86 (6) 539-544. 
Rasha Maher El-Sayed Bhnsawy

FEDIOL (2012):

\section{Annual}

Vegetable

production,

exports

consumption.

(www.fediol.eu).

Firestone D (1993):

Worldwide regulation of frying fats and oils, INFORM vol 4 no12:1366 - 1371 .

Frankel E (1984):

\section{Lipid}

oxidation:

Mechanisms, products and biological significance. Journal of the American Oil Chemists' Society. 61 (12) 1908-1917.

\section{Frankel EN (2007):}

Antioxidants in food and biology Dundee.The Oily Press LTD.
Gharby S; Harhar H; El Monfalouti H; Kartah B; Maata N; Guillaume $D$ and Charrouf $\quad Z$ (2011):

Chemical and oxidative properties of olive and argan oils sold on the Moroccan market A comparative study. Mediterranean, Journal of Nutrition and Metabolism. 44: 1-8.

Gharby S; Harhar H; Boulbaroud $\mathrm{S}$; Bouzoubaâ Z; el Madani N; Chafchaouni I and Charrouf $Z$ (2014):

The stability of vegetable oils (sunflower, rapeseed and palm) sold on the Moroccan market at high temperature. International Journal of Chemical and Biochemical Sciences, 5, 47-54.

Gharby S; Harhar H; Guillaume D; Haddad A and Charrouf $\mathrm{Z}(\mathbf{2 0 1 2})$ :
Gertz C; Klostermann S; and Kochhar SP (2000):

Eur. J. Lipid Sci. Techn., 102, 543 
Physiochemical and nutritional values of some blends of vegetable oils with palm olein compared to some cooking oils of Tamouin Cards

Rasha Maher El-Sayed Bhnsawy

The origin of virgin

argan Oil's high oxidative stability

unraveled.

Natural

Product

Communications 7: 621624.

\section{Griffin BA (2008):}

How relevant is the ratio of dietary omega- 6 to omega -3

polyunsaturated fatty acids to cardiovascular disease risk? Evidence from the OPTILIP study.Journal of Current Opinion in Lipidology 19 (1): 57-62.

\section{Gulla $S$ and Waghray $K$} (2012):

Blending of oils: A case study on storage stability and sensory characteristics of a ready to eat extruded snack.Journal of nutrition, Dietetics and food science, volume 2, issue 1

Idun-Acquah N; George Y; Obeng GY and Mensah E (2016):
Repetitive Use of Vegetable Cooking Oil and Effects on Physico-Chemical Properties - Case of Frying with Redfish (Lutjanusfulgens). Science and Technology 6(1): 814.

\section{Judde A (2004):}

Prevention de l'oxidation des

acidsgrassdansunproduit cosmétique: mécanismes, conséquences, moyens de mesure, quels antioxidants pour quells applications? Oléagineux, Corps Gras, Lipides11: (6)414-418.

Kim J; Kim DN; Lee SH; Yoo SH and Lee $S$ (2010):

Correlation of fatty acid composition of vegetable oils with rheological behavior and oil uptake. Food Chem.118, 398402.

Kim HJ and Min DB (2008):

Tocopherol stability and prooxidant mechanisms 
Physiochemical and nutritional values of some blends of vegetable oils with palm olein compared to some cooking oils of Tamouin Cards

Rasha Maher El-Sayed Bhnsawy

of oxidized tocopherols in

lipids.In Food lipids:

chemistry, nutrition, and

biotechnology. Ed C.

Press. 435-447.

Kochhar SP(2000):

Stable and healthful frying oil for the $21 \mathrm{st}$ century.

Inform11:642-5.

Labuza TP and Dugan LR(1971):

Kinetics of lipid oxidation in foods. $C R C$ Critical Reviews in Food

Technology. 2 (3) 355 405.

Leong XF; Ng CY; Jaarin and Mustafa MR (2015):

Effects of repeated heating of cooking oils on antioxidants content and endothelial function. Austin J. PharmacolTher 3(2): id1068: 1-7.

Matthäus B D; Gillaume S; Gharby A; Haddad H;
Harhar and $\mathbf{Z}$ Charrou

F (2010):

Effect of processing on the quality of edible argan oil. Food Chemistry. 120: 426-432.

Mishra $S$ and Manchanda SC(2012):

Cooking oils for heart health.J. Preventive

Cardiology. Vol.1 no.3:123-131.

Mozaffarian D; Ascherio A; Hu FB; Stampfer MJ; Willett WC;Siscovick DS and Rimm EB (2005):

Interplay

Between

Different

Polyunsaturated Fatty Acids and Risk of Coronary Heart Disease in Men.Circulation 111 (2): 157-64.

Murakoshi M; Nishino H; Satomi Y; Takayasu J; Hasegawa T; Tokuda H; Iwashima A; Okuzumi J; Okabe H; Kitano H, et al. (1992): 
Physiochemical and nutritional values of some blends of vegetable oils with palm olein compared to some cooking oils of Tamouin Cards

Rasha Maher El-Sayed Bhnsawy

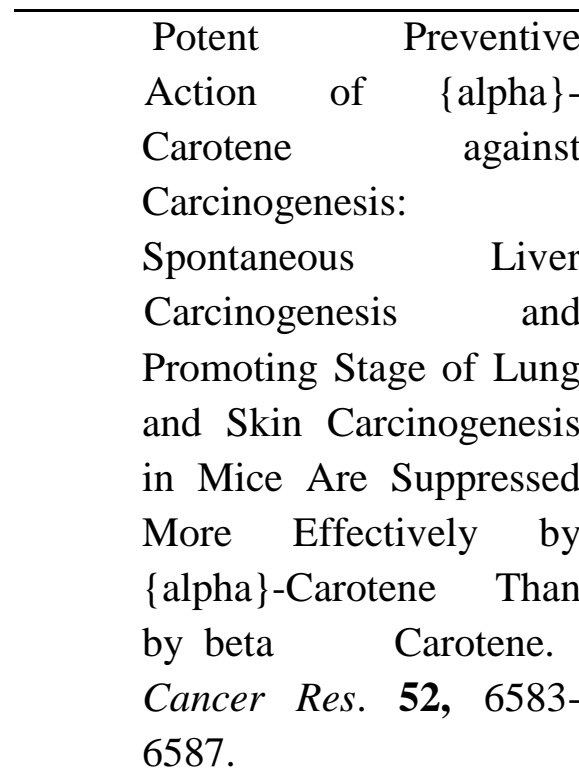

Nielsen NS(2010):

Food Analysis Laboratory Manual.ISBN: 978-14419-1462-0.

Ramsden CE; Zamora D; Leelarthaepin B; Majchrzak-Hong SF; Faurot KR; Suchindran CM; Ringel A; Davis JM and Hibbeln JR(2013):

"Use of dietary linoleic acid for secondary prevention of coronary heart disease and death: evaluation of recovered data from the Sydney Diet Heart Study and updated meta-analysis." Journal of British Medicine (Clinical research ed.) 346.

Roiaini M; Ardiannie T and "Norhayati H (2015):

Physicochemical properties of canola oil, olive oil and palm olein blends. International Food Research Journal 22(3): 1227-1233.

Siddique BM; Ahmad A; Ibrahim MH; Hena S; Rafatullah $M$ and Omar A KM (2010):

Physico - chemical properties of blends of palm olein with other vegetable oils. Grasas $y$ Aceites, 61 (4), octubrediciembre, 423-429.

Stevenson SG; Jenser $\mathrm{V}$ and Eskin M, JOACS, 61, 1102 (1984):

Tabee ES; AzadmardDimirchi, M Jagerstad, PC Dutta, J. Am. Oil Chem. Soc., $\quad \mathbf{8 5}, \quad 857$ (2008). 
Physiochemical and nutritional values of some blends of vegetable oils with palm olein compared to some cooking oils of Tamouin Cards

Rasha Maher El-Sayed Bhnsawy

Tawfik MS and Huyghebaert A(1999):

Interaction of packaging materials and vegetable oils: oil stability. Journal of Food Chemistry 64: 451-459.

\section{Velasco $J$ and Dobarganes}

C(2002):

Oxidative Stability of Virgin olive Oil.

European Journal of Lipid Science and Technology. 104: 661676.
Willett WC (2007):

The role of dietary n- 6 fatty acids in the prevention of cardiovascular disease. Journal of Cardiovascular Medicine 8(1): 42-45. 
Physiochemical and nutritional values of some blends of vegetable oils with palm olein compared to some cooking oils of Tamouin Cards

Rasha Maher El-Sayed Bhnsawy

Table (1)

\begin{tabular}{|l|l|l|l|}
\hline $\begin{array}{l}\text { Blend } \\
\text { No. }\end{array}$ & Sunflour oil & Soybean oil & Palm olein \\
\hline $\mathbf{1}$ & $25 \%$ & $25 \%$ & $50 \%$ \\
\hline $\mathbf{2}$ & $20 \%$ & $20 \%$ & $60 \%$ \\
\hline $\mathbf{3}$ & $15 \%$ & $15 \%$ & $70 \%$ \\
\hline $\mathbf{4}$ & \multicolumn{2}{|l|}{ Tamouin oil (sunflower oil) } \\
\hline $\mathbf{5}$ & \multicolumn{2}{|l|}{ Tamouin oil (soybean oil) } \\
\hline $\mathbf{6}$ & \multicolumn{2}{|l|}{ Tamouin oil from Giza (sunflower oil + soybean oil) } \\
\hline $\mathbf{7}$ & \multicolumn{2}{|l|}{ Tamouin oil from Sharqia (sunflower oil + soybean oil) } \\
\hline $\mathbf{8}$ & \multicolumn{2}{|l|}{ Tamouin oil from Qaliubia (sunflower oil + soybean oil) } \\
\hline
\end{tabular}

Table (2): Some physical properties of three prepared blends of oils comparative with other five collected samples.

\begin{tabular}{|c|c|c|c|c|c|}
\hline $\begin{array}{l}\text { Prepared } \\
\text { blends }\end{array}$ & $\begin{array}{l}\text { Smoke } \\
\text { point } \\
\left({ }^{\circ} \mathrm{C}\right)\end{array}$ & $\begin{array}{l}\text { Moisture } \\
(\%)\end{array}$ & $\begin{array}{l}\text { Density } \\
\text { ( g/ml) }\end{array}$ & $\begin{array}{l}\text { Viscosity } \\
\text { (CTP) }\end{array}$ & $\begin{array}{l}\text { Cloud } \\
\text { point } \\
\left({ }^{\circ} \mathrm{C}\right)\end{array}$ \\
\hline 1 & $238 \pm 1$ & $0.20 \pm 0.01$ & 0.924 & $50 \pm 0.5$ & $8.2 \pm 0.1$ \\
\hline 2 & $238 \pm 1$ & $0.20 \pm 0.01$ & 0.920 & $55 \pm 0.5$ & $8.6 \pm 0.1$ \\
\hline 3 & $236 \pm 1$ & $0.21 \pm 0.01$ & 0.910 & $60 \pm 0.5$ & $9.3 \pm 0.1$ \\
\hline \multicolumn{6}{|l|}{$\begin{array}{l}\text { Collected } \\
\text { samples }\end{array}$} \\
\hline 4 & $232 \pm 1$ & $0.23 \pm 0.01$ & 0.926 & $40 \pm 0.5$ & $6.5 \pm 0.1$ \\
\hline 5 & $232 \pm 1$ & $0.23 \pm 0.01$ & 0.928 & $45 \pm 0.5$ & $6.2 \pm 0.1$ \\
\hline 6 & $233 \pm 1$ & $0.2 \pm 0.01$ & 0.930 & $45 \pm 0.5$ & $7.3 \pm 0.1$ \\
\hline 7 & $230 \pm 1$ & $0.22 \pm 0.01$ & 0.927 & $50 \pm 0.5$ & $7.7 \pm 0.1$ \\
\hline 8 & $230 \pm 1$ & $0.22 \pm 0.01$ & 0.929 & $45 \pm 0.5$ & $6.9 \pm 0.1$ \\
\hline
\end{tabular}

Mean \pm SDStandard deviation values are expressed as mean of samples analyzed in triplicates 
Physiochemical and nutritional values of some blends of vegetable oils with palm olein compared to some cooking oils of Tamouin Cards

Rasha Maher El-Sayed Bhnsawy

Table (3): Some chemical properties of three prepared blends of oils comparative with other five collected samples

\begin{tabular}{|c|c|c|c|c|}
\hline $\begin{array}{l}\text { Prepared } \\
\text { blends }\end{array}$ & $\begin{array}{l}\text { Acid value } \\
\text { (mg KOH/g } \\
\text { oil) }\end{array}$ & $\begin{array}{l}\text { Peroxide } \\
\text { value } \\
(\mathrm{meq} / \mathrm{kg})\end{array}$ & $\begin{array}{l}\text { Saponification } \\
\text { value } \\
(\mathrm{mg} \mathrm{KOH} / \mathrm{g})\end{array}$ & $\begin{array}{l}\text { Iodine } \\
\text { value } \\
(\mathrm{g} / 100 \mathrm{~g})\end{array}$ \\
\hline 1 & $0.14 \pm 0.01$ & $4.68 \pm 0.5$ & $187.54 \pm 1$ & $114.92 \pm 1$ \\
\hline 2 & $0.14 \pm 0.01$ & $5.25 \pm 0.5$ & $189.12 \pm 1$ & $112.58 \pm 1$ \\
\hline 3 & $0.12 \pm 0.01$ & $5.93 \pm 0.5$ & $189.51 \pm 1$ & $112.84 \pm 1$ \\
\hline \multicolumn{5}{|l|}{$\begin{array}{l}\text { Collected } \\
\text { samples }\end{array}$} \\
\hline 4 & $0.19 \pm 0.01$ & $8.52 \pm 0.5$ & $192.14 \pm 1$ & $124.14 \pm 1$ \\
\hline 5 & $0.19 \pm 0.01$ & $8.89 \pm 0.5$ & $192.52 \pm 1$ & $122.57 \pm 1$ \\
\hline 6 & $0.22 \pm 0.01$ & $9.13 \pm 0.5$ & $195.24 \pm 1$ & $126.28 \pm 1$ \\
\hline 7 & $0.18 \pm 0.01$ & $7.86 \pm 0.5$ & $189.85 \pm 1$ & $128.59 \pm 1$ \\
\hline 8 & $0.17 \pm 0.01$ & $6.83 \pm 0.5$ & $190.27 \pm 1$ & $122.95 \pm 1$ \\
\hline
\end{tabular}

Mean $\pm S D$ : Standard deviation values are expressed as mean of samples analyzed in triplicate

Table (4): Rancimat at $120^{\circ} \mathrm{C}$ of three prepared blends of oils comparative with other five collected samples

\begin{tabular}{|l|l|}
\hline Prepared blends & Rancimat $(\mathbf{h})$ \\
\hline 1 & 9.25 \\
\hline 2 & 7.52 \\
\hline 3 & 6.13 \\
\hline Collected samples & \\
\hline 4 & 3.28 \\
\hline 5 & 2.50 \\
\hline 6 & 3.47 \\
\hline 7 & 1.66 \\
\hline 8 & 1.64 \\
\hline
\end{tabular}


Table (5): Fatty acid composition (expressed as percentage of total of fatty acids) of three prepared blends of oils comparative with other five collected samples

\begin{tabular}{|c|c|c|c|c|c|c|c|c|}
\hline \multirow[t]{2}{*}{ Acids } & \multicolumn{3}{|c|}{ Prepared blends } & \multicolumn{5}{|c|}{ Collected samples } \\
\hline & 1 & 2 & 3 & 4 & 5 & 6 & 7 & 8 \\
\hline C 16:0 & 13.15 & 11.01 & 10.77 & 10.72 & 6.09 & 10.87 & 6.65 & 6.55 \\
\hline C 16:1 & 0.12 & 0.13 & 0.11 & 0.11 & 0.14 & 0.07 & 0.11 & 0.22 \\
\hline C 18:0 & 4.35 & 3.97 & 4.25 & 4.19 & 3.74 & 4.78 & 3.57 & 3.62 \\
\hline C 18:1 & 25.05 & 24.89 & 24.77 & 24.96 & 26.51 & 21.51 & 24.93 & 25.65 \\
\hline C 18:2 & 49.51 & 52.06 & 52.44 & 52.36 & 61.91 & 55.01 & 63.13 & 62.38 \\
\hline C 18:3 & 6.59 & 6.63 & 6.29 & 6.32 & 0.22 & 6.67 & 0.55 & 0.35 \\
\hline C 20:0 & 0.26 & 0.49 & 0.27 & 0.47 & 0.39 & 0.39 & 0.25 & 0.18 \\
\hline C 22:0 & 0.16 & 0.49 & 0.30 & 0.43 & 0.87 & 0.39 & 0.29 & 0.29 \\
\hline SFA & 17.91 & 15.94 & 15.41 & 15.77 & 11.09 & 16.40 & 10.74 & 10.60 \\
\hline MUFA & 25.17 & 25.01 & 24.88 & 25.06 & 26.64 & 21.58 & 25.04 & 25.86 \\
\hline PUFA & 56.11 & 58.68 & 58.73 & 58.68 & 62.13 & 61.67 & 63.67 & 62.72 \\
\hline
\end{tabular}

SFA: Saturated fatty acids. MUFA: mono-unsaturated fatty acids, PUFA: Polyunsaturated fatty acids 
Physiochemical and nutritional values of some blends of vegetable oils with palm olein compared to some cooking oils of Tamouin Cards

Rasha Maher El-Sayed Bhnsawy

Table (6) Sensory evaluation for potato chips fried in three prepared blends of oils comparative with other five collected samples

\begin{tabular}{|c|c|c|c|c|c|}
\hline \multirow{2}{*}{$\begin{array}{l}\text { Prepared } \\
\text { blends }\end{array}$} & \multicolumn{5}{|c|}{ Sensory evaluation } \\
\hline & Color & Taste & Odor & Texture & Acceptance \\
\hline 1 & $\begin{array}{c}9.67^{\mathrm{a}} \pm \\
0.52\end{array}$ & $\begin{array}{c}9.33^{\mathrm{a}} \pm \\
0.82\end{array}$ & $\begin{array}{c}9.33^{\mathrm{a}} \pm \\
0.52\end{array}$ & $\begin{array}{c}10.0^{\mathrm{a}} \pm \\
0.00\end{array}$ & $\begin{array}{c}9.67^{\mathrm{a}} \pm \\
0.52\end{array}$ \\
\hline 2 & $\begin{array}{c}9.67^{\mathrm{a}} \pm \\
0.52\end{array}$ & $\begin{array}{c}9.33^{\mathrm{a}} \pm \\
0.82\end{array}$ & $\begin{array}{c}9.17^{\mathrm{a}} \pm \\
0.75\end{array}$ & $\begin{array}{c}9.83^{\mathrm{a}} \pm \\
0.41\end{array}$ & $\begin{array}{c}9.33^{\mathrm{a}} \pm \\
0.82\end{array}$ \\
\hline 3 & $\begin{array}{c}9.67^{\mathrm{a}} \pm \\
0.52\end{array}$ & $\begin{array}{c}9.33^{\mathrm{a}} \pm \\
0.52\end{array}$ & $\begin{array}{c}9.83^{\mathrm{a}} \pm \\
0.41\end{array}$ & $\begin{array}{c}9.67^{\mathrm{a}} \pm \\
0.52\end{array}$ & $\begin{array}{c}9.67^{\mathrm{a}} \pm \\
0.52\end{array}$ \\
\hline $\begin{array}{l}\text { Collected } \\
\text { samples }\end{array}$ & & & & & \\
\hline 4 & $\begin{array}{c}8.67^{b} \pm \\
0.51\end{array}$ & $\begin{array}{c}8.17^{b} \pm \\
0.41\end{array}$ & $\begin{array}{c}8.33^{b} \pm \\
0.52\end{array}$ & $\begin{array}{c}8.83^{b} \pm \\
0.41\end{array}$ & $\begin{array}{c}8.33^{b} \pm \\
0.52\end{array}$ \\
\hline 5 & $\begin{array}{c}8.17^{b c} \pm \\
0.75\end{array}$ & $\begin{array}{c}8.17^{b} \pm \\
0.41\end{array}$ & $\begin{array}{c}8.33^{b} \pm \\
0.51\end{array}$ & $\begin{array}{c}8.67^{b} \pm \\
0.52\end{array}$ & $\begin{array}{c}8.17^{b} \pm \\
0.41\end{array}$ \\
\hline 6 & $\begin{array}{c}9.67^{\mathrm{a}} \pm \\
0.82\end{array}$ & $\begin{array}{c}9.00^{\mathrm{a}} \pm \\
0.62\end{array}$ & $\begin{array}{c}9.17^{\mathrm{a}} \pm \\
0.41\end{array}$ & $\begin{array}{c}9.67^{\mathrm{a}} \pm \\
0.52\end{array}$ & $\begin{array}{c}9.33^{\mathrm{a}} \pm \\
0.52\end{array}$ \\
\hline 7 & $\begin{array}{c}7.67^{c} \pm \\
0.52\end{array}$ & $\begin{array}{c}7.50^{b c} \pm \\
0.54\end{array}$ & $\begin{array}{c}7.33^{c} \pm \\
0.82\end{array}$ & $\begin{array}{c}7.83^{c} \pm \\
0.41\end{array}$ & $\begin{array}{c}7.33^{c} \pm \\
0.52\end{array}$ \\
\hline 8 & $\begin{array}{c}7.83^{\mathrm{c}} \pm \\
0.41\end{array}$ & $\begin{array}{c}7.17^{c} \pm \\
0.41\end{array}$ & $\begin{array}{c}7.50^{c} \pm \\
0.55\end{array}$ & $\begin{array}{c}7.50^{c} \pm \\
0.55\end{array}$ & $\begin{array}{c}7.33^{c} \pm \\
0.52\end{array}$ \\
\hline LSD & 0.68 & 0.69 & 0.67 & 0.52 & 0.64 \\
\hline
\end{tabular}

Mean \pm SD: Standard deviation values are expressed as mean of samples analyzed in triplicates 


\section{القيم الفيزيائية و الكيمائية و التغذوية لبعض خلطات من \\ الزيوت النباتية مع زبت اولين النخيل و مقارنتها ببعض زيوت الطهي الموز عة على بطاقات التموين \\ د./ رشــا ماهـــر السـيل بـنســاوى

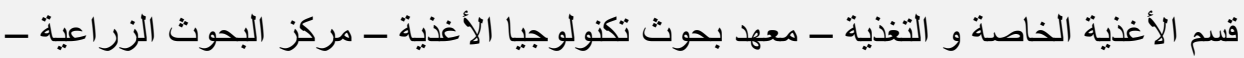 الجيزة - جمهورية مصر العربية

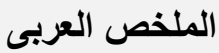

تعتبر خلط الزبت حل في انتاج الزبوت النباتية التى لها خاصبية الثبات فى التخزبن

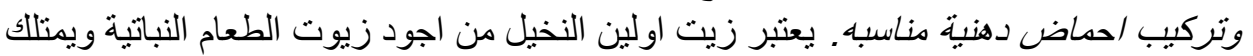
خاصية الثبات تجاه التزنخ و الأكسدة. صدمت هذه الدراسة للتعرف على على أفضل المخالبط

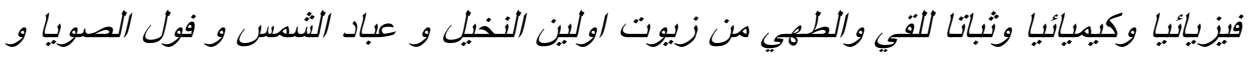

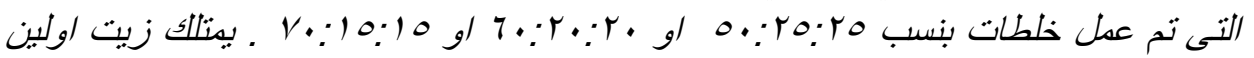

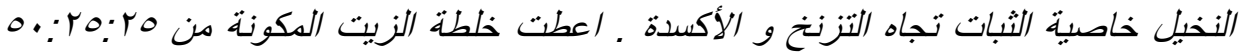

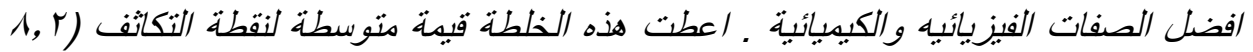

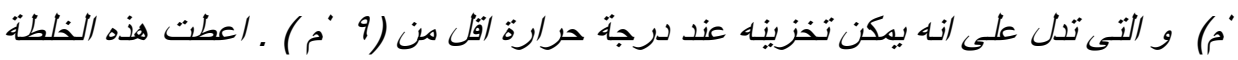

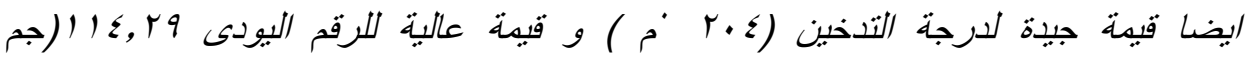

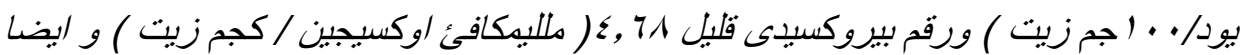

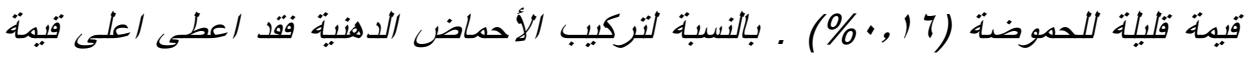

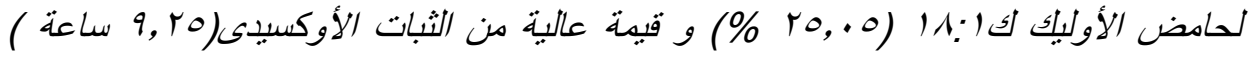
مقارنة بالأنواع الأخرى من الخلطات. وعند قلي شرائح البطاطس فحى هذه الخلطات كانت

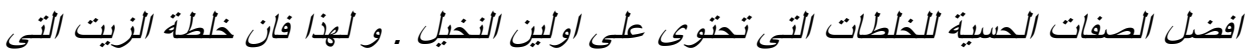

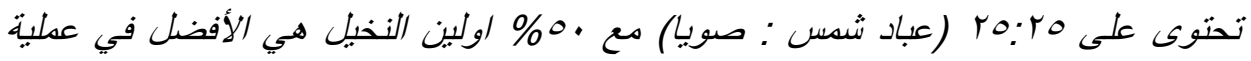

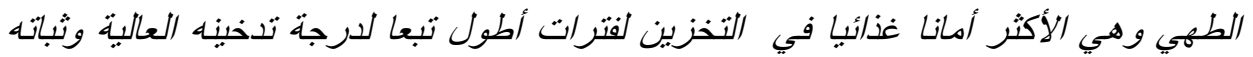
الاوكسبيدي.

الكلمات المفتاحية:خليط الدهون - زبت النخبي- زبت دوار الشدس- زبيث الصوبا - زبيت بطاقات

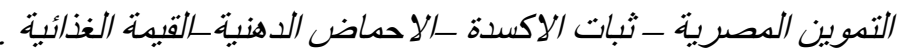

